\title{
Early performance of planted hybrid larch: Effects of mechanical site preparation and planting depth
}

Mario Buitrago ${ }^{1}$, Alain Paquette ${ }^{1 *}$, Nelson Thiffault ${ }^{1,2}$, Nicolas Bélanger ${ }^{1,3}$ and Christian Messier $^{1,4}$

${ }^{1}$ Centre for Forest Research (CEF), Université du Québec à Montréal, PO Box 8888, Centre-ville Station, Montréal, QC, Canada H3C 3P8

${ }^{2}$ Direction de la recherche forestière, Ministère des Forêts, de la Faune et des Parcs du Québec, 2700 Einstein, Québec, QC, Canada G1P 3W8

${ }^{3}$ Téluq, Université du Québec, 5800 rue Saint-Denis, Bureau 1105, Montréal (Québec), Canada H2S 3L5

${ }^{4}$ Institut des Sciences de la Forêt Tempérée (ISFORT), Université du Québec en Outaouais, 58 rue Principale, Ripon, QC, Canada J0V 1V0 *Corresponding author.

Email: alain.paquette@gmail.com; Phone: (514) 987-3000 x4866; Fax: (514) 987-4647

\begin{abstract}
Some site preparation is generally recommended to enhance the growth and survival of planted and naturally regenerated seedlings, but must be justified both economically and environmentally. More severe preparation is thought to be necessary for intensive plantation silviculture, e.g., using fast-growing, ameliorated stocks, especially in boreal ecosystems. Although not justified scientifically, deep-planting of seedlings is often
\end{abstract}


discouraged and may even be financially penalized in eastern Canada. We thus evaluated early seedling growth and survival of hybrid larch (Larix x marschlinsii Coaz) in an experiment including mechanical site preparation and planting depth treatments. Our results suggest that satisfactory early hybrid larch establishment and growth could be met using low environmental impact or low cost treatments (such as soil inversion using an excavator or single-pass disk trenching), and that depth of planting has no negative effect. Structural equation modelling (SEM) was used to explore causal relationships between factors influencing seedling performance at the local scale (planting microsites), including soil moisture, soil temperature, surrounding vegetation, and seedling nutrition. SEM analysis supported the absence of overall differences among treatments, while also highlighting the negative impact of increased soil water content where drainage was suboptimal, as well as the unexpected positive impact of increased competition on growth mostly through seedling nutrition, among others. These early observations will need to be confirmed over a longer period, as well as with a more comprehensive assessment of site environmental conditions and competition intensity.

Keywords: Structural equation modelling (SEM), planting microsite, hybrid larch, mechanical site preparation, forest functional zoning (TRIAD), intensive silviculture, planting depth 


\section{Introduction}

It is generally accepted that forest plantation productivity is positively correlated with management intensity (Löf et al. 2012; Paquette and Messier 2013; Bilodeau-Gauthier et al. 2013). Consequently, most silvicultural guides advocate the use of intensive soil disturbance to create appropriate planting microsites for seedling establishment (Örlander et al. 1990; von der Gonna 1992; Prévost and Thiffault 2013). Indeed, soil scarification is recognized to increase soil temperature and moisture, and favour organic matter mineralization especially in boreal ecosystems (Prévost 1992). Seedling growth and survival are enhanced, as biotic and abiotic conditions are positively modified (Grossnickle and Heikurinen 1989), which can lead to increased timber supply in the long-term (Boateng et al. 2006). Under non-optimal conditions, seedlings suffer various stresses that can negatively affect their physiology and growth (Margolis and Brand 1990; Grossnickle 2005, 2012). Site preparation must however be adapted to site characteristics, as inappropriate soil manipulation can lead to unwanted effects. For example, high soil temperatures in dry sites can severely limit root growth, cause the malfunctioning of photosynthetic mechanisms, or even kill root cells, mainly because of desiccation (Kramer and Boyer 1995; Pallardy 2010).

Vegetation that surrounds planted seedlings is generally considered to be undesirable, as it can compete with the latter for environmental resources, or release allelopathic compounds (Balandier et al. 2006). Indeed, a reduced vegetation cover tends to increase resource availability to the newly planted seedlings (Walstad and Kuch 1987). In contexts where the use of chemical herbicides is restricted such as in Québec, Canada (Thiffault 
and Roy 2011), intensive site preparation can help reduce the need for repeated and expensive manual tending treatments that are used to manage competing vegetation after plantation establishment (Gagné and Paquette 2008). However, non-crop vegetation can also enhance seedling growth and survival under some conditions (Holmgren et al. 1997; Brooker et al. 2008; Bruno et al. 2003). For example, in intermediate to mature boreal forest stands, Longpré et al. (1994) found that jack pine (Pinus banksiana Lamb.) had larger diameters when growing in mixtures with paper birch (Betula papyrifera Marsh.) compared to growing in either pure stands or mixtures with trembling aspen (Populus tremuloides Michx.). Facilitation mechanisms by surrounding vegetation may include improvement in soil conditions (e.g., moisture, nutrients and structure), regulation of microclimate, or reduction of insect attacks (Brooker et al. 2008). Thus, the use of site preparation as a vegetation management tool must be balanced with the potential loss of nurse plant effects of non-crop vegetation.

Silvicultural guides in Canada generally discourage planting the root collar of seedlings deeper than $3 \mathrm{~cm}$ below the soil surface, a practice which stems mostly from tradition (Schwan 1994). Deep planting is sometimes even financially penalized, despite the lack of scientific evidence for a detrimental effect (Paquette et al. 2011). In contrast, studies on both conifers (Paquette et al. 2011; Tarroux et al. 2014) and broadleaf species (Gemmel et al. 1996) have reported either no negative or actual positive effects of deep planting on seedling growth, absolute height above ground, or survival. Moreover, deep planting may reduce the risk of frost heaving (Sahlén and Goulet 2002; de Chantal et al. 2009), eliminate root collar exposition due to planting at too shallow a depth (Paquette et 
al. 2011) and stimulate root production (Sutton 1995; Tarroux et al. 2014). Deep planting has also been recomended to improve access to soil water where moisture is limiting (Sutherland and Foreman 1995). This is important for plantation productivity, as the choice of planting seedlings at deeper or shallower depths could determine overall plantation success.

In a context where high-yield forest plantations are expected to respond to an increasing proportion of world demand for wood products (Paquette and Messier 2010), it is imperative that management guidelines be identified that would guarantee the achievement of production objectives. To do so, we must identify and disentangle the mechanisms that are responsible for positive or negative effects of site preparation, surrounding vegetation, and planting depth on seedling performance. Such knowledge is critical for the successful management of hybrid larch (Larix x marschlinsii Coaz), a tree of interest for high-yield silviculture in northern ecosystems for which limited information is available (Messier et al. 2003; Messier et al. 2009; Gagné and Paquette 2008).

This research is a part of a forest functional zoning project in Eastern Canada where a three-pronged approach is used: ecosystem-based management, intensive silviculture, and conservation (Messier et al. 2009). Hybrid larch, together with hybrid poplars and other fast-growing species, forms the basis of the intensive plantation forestry part of this forest zoning project. We established a gradient of planting microsite disturbance (i.e., a gradient of resource availability) and a planting depth treatment to test if early growth of 
hybrid larch seedlings: $i$ ) is directly and proportionally related to microsite disturbance, and $i$ ) is affected by planting depth. We hypothesized that seedling growth and survival: i) is enhanced by increasing microsite disturbance and $i i$ ) is not affected by planting depth in general, but that iii) deep-planted seedlings in raised microsites (mounds) have higher growth and survival than shallow-planted ones. We constructed structural equation models (SEM) (Pugesek et al. 2003; Shipley 2000; Lei and Wu 2007) to identify the key variables and causal paths that influenced seedling growth locally at the plantation microsite-scale after two growing seasons.

\section{Material and methods}

Study area and site description

The study area is located within the zone where the TRIAD project is taking place (Messier et al. 2009), in south-central Québec (Canada), about 250 km north of Montréal $\left(47^{\circ} 37^{\prime} 19^{\prime \prime} \mathrm{N}, 72^{\circ} 49^{\prime} 55 \mathrm{~W}\right)$, within the balsam fir (Abies balsamea (L.) Mill.) - yellow birch (Betula alleghaniensis Britt.) bioclimatic domain (Saucier et al. 2009). The climate is cold continental with temperate summers, no dry season, and a growing season of 170 days (Saucier et al. 2009). From 1971 to 2000, average annual temperature was $3.4{ }^{\circ} \mathrm{C}$, and average annual precipitation was $940 \mathrm{~mm}$, of which $24 \%$ fell as snow. The site is located on a coarse-textured glacial till deposit that is 50 to $100 \mathrm{~cm}$ thick. Drainage is moderate and slopes vary between $3 \%$ and $15 \%$. The previous stand was harvested in October 2009 with protection of advance regeneration (5\% variable retention cut); it was dominated by balsam fir, paper birch, yellow birch, red maple (Acer rubrum L.), and 
black spruce (Picea mariana (Mill.) BSP). The site is typical of those used for reforestation with exotic larches (including hybrid larch) in the TRIAD project.

\section{Experimental design and treatments}

In November 2009, we established an experiment to test the effects of mechanical site preparation and planting depth on the growth, survival, and physiology of hybrid larch seedlings. The experimental design, covering $\sim 27 \mathrm{ha}$, is a replicated split-plot assignment (Fig. 1), with site preparation as the whole-plot (main treatment) level and planting depth as the sub-plot level treatment. The experiment was set up using two large classes of mechanical site preparation methods (trenching and mounding), which varied in configuration and intensity (Table 1). Trenching (Fig. 2 - top row) was performed with two adjustable rotating toothed disks that mixed the organic layer with the mineral soil. Mounding was achieved with an excavator equipped with a $60 \mathrm{~cm}$-wide bucket; the mounds were composed of bare mineral soil on top of the inverted organic layer (Fig. 2 bottom row). We arranged the treatments within three replicated blocks of $\sim 6$ ha each (Fig. 1). Each block was divided into six adjacent main plots of around one hectare to which we randomly assigned one of the following mechanical site preparation methods (Table 1; Fig. 2): i) Simple (T); ii) Double adjacent (T-Da); iii) Double intensive (T-Di); iv) Mounds (M); and Inversions (M-inv). A sixth method, which is termed Partial intensive (T-Pi), was also established in the same fashion as T-Di, except that the scarifier skipped one pass (the equivalent of two trenches), thereby disturbing only half of the harvested area. The T-Di and T-Pi treatments are not expected to differ in terms of planting microsite characteristics over the short-term, since only the spatial layout of the 
trenches was changed; differences are expected to appear only in the mid-term (after 10 to 15 years), at the plot level. These two methods, therefore, were grouped as T-Di, resulting in 5 mechanical site preparation treatments for the purposes of this 2-year-long study. All treatments were expected to reduce competing vegetation at the planting microsite scale. These consisted of trenching by crushing and mixing vegetation with the mineral soil, and mounding by burying vegetation under the mineral soil (Sutton 1993). Consequently, seedlings have immediate access to soil organic matter due to the trenching treatments, whereas, in the mounding treatments, seedlings first have to extend their roots down into sandwiched organic layer. Thus, at the seedling (or microsite) level, the $\mathrm{M}$-inv and $\mathrm{M}$ treatments are considered the most disturbed microsites, $\mathrm{M}$ even more so, because of its elevated position above the ground surface (Fig. 2, Table 1). Therefore, the resulting gradient of increasing soil disturbance at the microsite level (i.e., for the planted tree) was: $\mathrm{T}<\mathrm{T}-\mathrm{Da}<\mathrm{T}-\mathrm{Di}<\mathrm{M}$-inv $<\mathrm{M}$. This ordering would be different if responses were considered at the stand-level, e.g., in terms of the treatments' environmental impacts (Table 1). This experiment did not include a control (unscarified) treatment per se, as many studies have already shown how the establishment of conifers is compromised on boreal sites if proper soil management is not used, especially in the absence of chemical vegetation management (Prévost and Dumais 2003; Thiffault and Jobidon 2006; Thiffault et al. 2013). Instead we used a "base treatment" (i.e. Simple - T) that would at least guaranty minimum seedling establishment.

In April 2010, the site was planted with a large planting stock hybrid larch, a species recognized for its intolerance to shade, waterlogged or drought conditions, and soils with 
low organic matter content (Robbins 1985; Carter and Selin 1987; Bergès and Chevalier 2001). Seedlings were produced by rooted cuttings (clone MEH-C2-ALO-2-1) in 320 $\mathrm{cm}^{3}$ containers at the St-Modeste governmental nursery (Québec, Canada). The hybrid Larix $\mathrm{x}$ marschlinsii is produced by crossing European larch (L. decidua Mill.) with Japanese larch (L. kaempferi (Lamb.) Carr.). Based on a nursery assessment of seedling characteristics conducted in November $2009(\mathrm{~N}=120)$, the seedling lot was (mean \pm SD) $42.6 \mathrm{~cm} \pm 9.6$ in height, $6.0 \mathrm{~mm} \pm 1.0$ in diameter, with a foliar $\mathrm{N}$ concentration of $8.35 \mathrm{~g}$ $\mathrm{kg}^{-1}$. Each main plot (i.e., each site preparation treatment) was divided into two subplots, to which we randomly assigned one of two root-collar planting depths: $0-3 \mathrm{~cm}$ or 3-10 cm (Fig. 1c). In the trenching treatments (T, T-Da, T-Di), planters were instructed to plant the seedlings at the hinge position (trench-berm interface; Fig. 2 - top) (Örlander et al. 1990). In the $M$ and $M$-inv treatments, one seedling per mound was planted close to the highest point of the microsite (Fig. 2 - bottom). Seedlings were hand-planted using planting shovels, $2 \mathrm{~m}$ apart in the T treatments and $3 \mathrm{~m}$ in the $\mathrm{M}$, to avoid intra-specific competition during the first few years of growth.

\section{Seedling measurements}

For the purpose of growth assessment we established two circular sampling units $(8 \mathrm{~m}$ radius) in every subplot (Fig. 1d). In the trenching treatments, the circular sampling units contained $\sim 40$ seedlings, whereas they contained $\sim 22$ seedlings in the mounding treatments due to mounds being created every $3 \mathrm{~m}$. All seedlings located within the sampling units were tagged and measured for height $(\mathrm{H}, \mathrm{cm})$ and ground-level diameter 
$(\mathrm{D}, \mathrm{mm})$ at the time of planting. Seedling dimensions and survival were re-assessed in October 2010 and October 2011 (after one and two growing seasons, respectively).

\section{Seedling nutrition and microsite characteristics}

Within each sampling unit, we randomly selected and marked four seedlings for a detailed assessment of foliar nutrition and microsite quality in 2011. For each of these 286 seedlings (two died before the end of the study), we measured current year foliar nutrient concentrations ( $\mathrm{N}, \mathrm{P}, \mathrm{K}, \mathrm{Ca}$, and $\mathrm{Mg}$, as a proxy for seedling nutrition), soil temperature and water content (as a proxy for the root microenvironment), and surrounding non-crop vegetation (competition intensity). At the end of August 2011, we collected $\sim 50$ needles, which had been growing in full sun, from each of the selected seedlings in every sampling unit. Needles were oven-dried $\left(65^{\circ} \mathrm{C}\right.$ for $\left.48 \mathrm{~h}\right)$, then crushed for $1 \mathrm{~min}$ in a vibratory micro-mill (Pulverisette 0 , Fritsch, Idar-Oberstein, RhinelandPalatinate, Germany). Subsequent tissue digestion was conducted in a $\mathrm{H}_{2} \mathrm{SO}_{4}-\mathrm{H}_{2} \mathrm{O}_{2}$ mixture (Parkinson and Allen 1975). Kjeldahl N in the digests was determined colorimetrically (FIA Quickchem, Lachat, Milwaukee, WI), while P, K, Ca, and Mg concentrations were determined by inductively coupled plasma spectrometry (ICAP9000, Thermo Instruments, Franklin, MA). Actual sample size for nutrient content varies from $283(\mathrm{~N})$ to 267 (all others) because some samples lacked sufficient material for lab analyses.

We used a Barnant 115 thermocouple (Model No. 600-2810, Barnant Co., Barrington, IL) to measure soil temperature within a $30 \mathrm{~cm}$ radius of each of the selected seedlings in 
each sampling unit. Soil temperature measurements were taken from one permanently installed thermocouple at $0-3 \mathrm{~cm}$ and $3-10 \mathrm{~cm}$ depth, depending upon planting depth treatment. Volumetric soil water content (\%) was taken from three locations in the same $30 \mathrm{~cm}$ radius around the seedlings and determined with time domain reflectometry probes (Field Scout TDR 200, Spectrum technologies, Plainfield, IL) at a constant depth (10 $\mathrm{cm})$. Temperature and moisture measurements were performed four times in 2011, between 9:30 and 12:30, on June 14-16 and 20-22, July 4-5 and August 4-5. Logistical constraints prevented us from obtaining continuous or more frequent readings, so we decided to concentrate our sampling efforts during the second growing season, when roots were no longer restricted to the plugs. Also, we distributed the sampling effort in that year to cover most of the growing season while avoiding periods following rainfall events.

In May 2011, which corresponded to the period of leaf-out, the proportion of vegetation surrounding the planted seedlings was estimated for a circular area of $4 \mathrm{~m}^{2}$ (Bullock 2006). We used a Nikon 4500 CoolPix that was equipped with a Nikon fisheye converter FC-E8 0.21 x lens (Nikon Corporation, Tokyo, Japan) to take downward-facing hemispherical photographs. Since the tallest seedlings and vegetation attained $1.3 \mathrm{~m}$ maximum height (one year after plantation), we placed the lens at $1.6 \mathrm{~m}$ above the ground surface. The $4 \mathrm{~m}^{2}$ area was delimited with a tubular red plastic hoop that was centred upon the seedling and horizontally placed for reference. Using GIMP 2 software (www.gimp.org) and colour thresholds, we expressed competing vegetation as the ratio of green to total pixels within the reference circle. This analysis approach is time 
consuming; we ended up analysing only a little more than half the photos, chosen at random within experimental units $(\mathrm{n}=152)$.

\section{Statistical analyses}

The design included 2211 seedlings at the beginning of the experiment, for which we evaluated survival every year. Mortality occurred mostly during the second season (see below) and 2181 living trees were available for growth analysis at the end of the first season; a few of these were excluded due to missing values for either height or diameter, or heavy damage due to wet snow or herbivory from moose. Total sample sizes per period (beginning of experiment, end of first year, end of second year) were 2021, 1987, 1776 seedlings for height, and 2017, 1986, 1776 for diameter, respectively.

Analysis of variance for repeated measurements (ANOVAR) was used to assess treatment effects on seedling dimensions (H and D) and survival over time, according to linear mixed-effects models that were based on the experimental design. To meet assumptions of normality and homoscedasticity, seedling height data were square-roottransformed, while diameter was ln-transformed prior to analysis. The ANOVAR were performed with the MIXED procedure of SAS 9.2 (SAS Institute, Cary, NC, USA), assuming a first-order autoregressive covariance structure. Effects were declared significant for a threshold value of $\alpha=0.05$. For the sake of clarity, we subsequently presented the back-transformed means with bias correction for both the height and diameter responses (Ung and Végiard 1988; Végiard and Ung 1993). The GLIMMIX procedure was used to analyze seedling survival (binomial data). 
Given the qualitative and structured nature of the treatments, we used a priori contrasts to compare the linear component of the growth curves for $\mathrm{H}$ and $\mathrm{D}$. We verified whether the linear component differed between the $0-3 \mathrm{~cm}$ and $3-10 \mathrm{~cm}$ treatment depths:

i) for all of the soil preparation treatments;

ii) trenching vs mounding;

iii) M vs M-inv;

iv) $\mathrm{T}$ vs double pass trenching (T-Da and T-Di);

v) T-Da vs T-Di; and

vi) double pass trenching (T-Da and T-Di) vs mounding ( $\mathrm{M}$ and $\mathrm{M}$-inv).

For these comparisons, we used a probability threshold of $P \leq 0.008$ following Bonferroni correction of $\alpha$ to identify significant differences.

For foliar nutrient concentration and microsite characteristics, analyses of variance (ANOVA) were applied to the subset data (four seedlings per sampling unit) to assess the effect of site preparation and planting depth, with blocks as random factors (REML). Tukey HSD tests were then used to assess pairwise comparisons. Using these data, we also constructed structural equation models (SEM) to identify key variables and causal paths influencing seedling height after two growing seasons. We used the lavaan package (version 0.5-10) that was developed by Rosseel (2012) in R (version 2.15.2) ( $\mathrm{R}$ Development Core Team 2008). Before SEM analysis, we verified normality of all variables with respect to height. Chi-square tests, which are considered an appropriate 
index for sample sizes such as ours and for variables that satisfy normality, were used to assess model fit (Shipley 2000; Hooper et al. 2008).

\section{Results}

Seedling dimensions, survival and foliar nutrients

Initial seedling dimensions (height and ground-level diameter assessed immediately after planting) were not significantly different between site preparation treatments. Those dimensions were (mean \pm SD) $39.3 \mathrm{~cm} \pm 9.7$ and $37.7 \pm 10.1$ in height for shallow and deep planted seedlings, respectively, and $4.6 \mathrm{~mm} \pm 1.0$ and $4.4 \pm 0.9$ in diameter. Deep planted seedlings therefore appeared slightly, yet significantly, smaller as expected because part of their stem had been buried. This negative bias towards deep-planted seedlings was ignored for later analyses, in effect putting them at a disadvantage and providing for a more conservative assessment of that effect. The reasoning is that to the manager, for deeper planting to be acceptable, it has to demonstrate no effect on operational growth, i.e. on the tree's actual dimensions from the ground (Paquette et al. 2011).

However we detected a significant site preparation $\times$ planting depth $\times$ time interaction for both height and ground-level diameter, which indicated that growth curves were not parallel; differences between treatments changed over time (Table 2, Fig. 3). A priori contrasts that compared site preparation treatments and planting depths enabled us to interpret and explain these results. For example, seedlings planted at 0-3 cm showed greater height growth in the double-pass trenching treatments (T-Da and T-Di) than in the 
mounding treatments $\left(t_{5734}=-0.86, P<0.001\right)$, whereas differences were not significant when seedlings were planted deeper $\left(t_{5734}=-0.43, P=0.669\right)$. Also, seedlings that were planted in the trenching treatments exhibited lower diameter increment than seedlings that were planted in the mounding treatments at the $3-10 \mathrm{~cm}$ depth $\left(t_{5729}=-5.15, P<\right.$ 0.001; Fig. 3), whereas the increase in diameter was similar for both groups for seedlings planted at the $0-3 \mathrm{~cm}$ depth $\left(t_{5729}=-0.42, P=0.674\right)$. After two growing seasons, seedling height varied from $108 \mathrm{~cm}$ (M-inv; 3-10 cm depth) to $124 \mathrm{~cm}$ (T-Da; 0-3 cm depth), while seedling ground-level diameter varied from $14.2 \mathrm{~mm}(\mathrm{~T} ; 3-10 \mathrm{~cm}$ depth) to $17.8 \mathrm{~mm}$ (M; 0-3 cm depth) (Fig. 3). In general, survival was high (89\%), with most mortality having occurred during the second growing season (10\%). About $57 \%$ of the dead seedlings were found in poorly drained microsites (not shown). Seedling survival appeared to be unaffected by site preparation, planting depth or their interactions, but seedling mortality was too infrequent for the statistical model to converge. Foliar nutrient concentrations were not significantly affected by either site preparation or planting depth (Table 3).

\section{Soil and microsite variables}

Among the four soil humidity measures taken in 2011, the first (mid-June) showed the most response to treatments and was therefore used for further analyses. The last two measures for soil temperatures (early July and August) were averaged and used for the same reason. Soil moisture and temperature were significantly influenced by site preparation treatments (Table 3). Soil water content was lower in the mounding treatment (M) compared to all other site preparation methods, which had similar values. The 
mounding treatment $(\mathrm{M})$ also differed from the remaining site preparation methods in terms of soil temperature; it was $1.9^{\circ} \mathrm{C}$ warmer in mounds than in the disk-trenching treatments (Table 3; averaged across both planting depths). As expected, soils were also cooler deeper beneath the ground surface by about $1.2^{\circ} \mathrm{C}$ on average. Competing vegetation cover was not significantly influenced by site preparation and averaged $48 \%$ during the second growing season (Table 3).

\section{Structural equation modeling (SEM)}

Based on preliminary correlation analyses between microsite characteristics and seedling dimensions (height and diameter) and on SEM model fitness, height was selected as the most responsive dependent variable. It was thus retained for further interpretation but the same trends were observed for diameter and for stem volume (not shown). For the sake of simplicity and parsimony, the explanatory factors used in the SEM were soil temperature, soil water content, percent vegetation cover, and a latent variable (a variable that is indirectly determined by directly measurable variables), which was composed of significant foliar nutrient concentration values $(\mathrm{N}, \mathrm{P}$ and $\mathrm{Ca})$. SEM analyses produced models that provided good fits to the complex interplay between the explanatory variables and seedling height after two growing seasons (Fig. 4, Table 4). Note that fit indices would be further improved by removing non-significant variables (left intentionally for ease of interpretation).

Causal pathways differed between seedlings that were planted at $0-3 \mathrm{~cm}$ and those that were planted at 3-10 cm (Fig. 4). The main difference between the $0-3 \mathrm{~cm}$ and $3-10 \mathrm{~cm}$ 
models, however, resided in the absence of a temperature effect for the shallow-planted seedlings. This factor affected the 3-10 seedlings through its negative effect on foliar nutrients. At both planting depths, moisture had a direct negative impact on seedling growth (albeit not significant at the 5\% threshold for shallow-planted trees), also expressed through a negative effect on seedling nutrition for the deep-planted. Seedling height was positively affected by foliar nutrition in both cases, as expected, but also through competing vegetation that had a positive impact on nutrition. Competing vegetation, however, had an additional negative direct effect on growth for deeperplanted trees (not significant at the 5\% threshold).

\section{Discussion}

Effects of site preparation and planting depths

We investigated the response of planted hybrid larch seedlings to a gradient of microsite disturbances and planting depths. We observed that, contrary to our prediction and most often reported in the literature, this gradient was not reflected in seedling growth and survival. Soil inversion has been shown to increase seedling growth and survival compared to both disk trenching and mounding after five growing seasons in Scandinavia (Örlander et al. 1998; Hallsby and Örlander 2004). These effects were related to increased nitrogen mineralization and improved root growth related to soil warming in the inversion treatment, compared to disking. Bilodeau-Gauthier et al. (2013) studied the influence of a gradient of mechanical site preparation intensity, fertilization and vegetation control on hybrid poplar seedlings over five years. They concluded that mounding (the most severe method in their study) was the best method for establishing 
this fast-growing and resource-demanding species. The benefits of mounding were also attributed to increased temperature and rates of nitrogen mineralization, compared to the other treatments. Although hybrid larch is also considered a fast-growing and resourcedemanding species, mounding did not lead to similar results in the present study. In fact, the most severe treatment resulted in the smallest growth response amongst all treatments after two growing seasons. These differences might be related to the length of the study; during these first two growing seasons, hybrid larch response was highly variable (Fig. 3) and none of the treatments we studied was associated with large resource limitations. Such limitations would probably appear only after canopy closure (Miller 1995). Also, competition cover at the microsite level remained limited over the study period; continued monitoring may reveal divergent growth patterns in the mid-term, as the microsites will gradually get invaded by competing species. Furthermore, it is possible that hybrid larch is a less nutrient demanding species than hybrid poplar, as shown by the low mortality we observed. Overall, the treatments we tested led to a small height difference between the least and the most effective ones $(+15 \%)$, with no immediate silvicultural consequences; seedlings in all treatments could be considered "free-to-grow" and, therefore, not requiring vegetation control according to standards used in Québec (Thiffault and Hébert 2013).

Similarly to the absence of a strong site preparation effect, deep- or shallow-planting did not influence seedling growth and survival, even if deep-planted trees actually had smaller height and diameter values at the start of the experiment due to the buried stem. The same absence of a detrimental effect was also reported for other conifer species after 
19 years in Québec (Paquette et al. 2011) and for broadleaf species in Scandinavia after three years (Gemmel et al. 1996). Tarroux et al. (2014) even reported that deep-planted black and white spruce (Picea glauca (Moench) Voss) seedlings (10-12 cm) had higher height and diameter growth compared to those planted normally at ground level, 17 years after planting.

This study did not include a "true" control treatment (i.e. undisturbed soil) since such treatment would have undoubtedly resulted in plantation failure based on empirical knowledge of hybrid larch silviculture in this region. We therefore compared our most intensive treatments to a less intensive treatment (i.e. Simple - T). It turned out that this latter treatment produced trees that had similar growth to those planted in the more intensive treatments. The overall similar early growth across treatments has important consequences for management. Our results suggest that managers can opt for less expensive options, such as simple disk trenching, or those treatments that are least damaging to the environment, such as inversion, depending upon local management constraints, with negligible effects on initial planting performance. However, it should be noted that this was a 2-year study and that short-term impacts of site preparation treatments are not always indicative of future trends (Munson et al. 1993). Site preparation effects are dynamic and may involve the progressive emergence of competing vegetation or changes in soil nutrient availability through time (Munson et al. 1993; Thiffault et al. 2004).

Causal relationships between environmental factors 
The lack of a site preparation effect on seedling growth and survival could be due in part to the relatively high local variation among planting microsites (i.e., within our plots), which would reduce the importance of local scarification effects relative to predetermined environmental growing conditions (drainage, resources, etc.). We therefore looked at the relationships between microsite quality (the result of both site preparation and pre-established conditions) and seedling performance using SEM, at the individual scale (Fig. 4; Table 4). These results illustrate that an increase in soil temperature and moisture can have deleterious effects on seedling growth, either directly or through seedling nutrition (more so for deeper-planted trees). Water was not limiting during these first two years. Rather, the excess of water affected trees negatively, as illustrated by seedling mortality occurring almost exclusively in poorly drained microsites. This effect was stronger on deeper-planted trees whose roots probably experienced even higher water content (measured at same depth in both treatments). Those results are clearly indicative of a species' sensitivity to waterlogged conditions.

Soil temperature in the mounding $(0-3 \mathrm{~cm})$ treatment reached $27^{\circ} \mathrm{C}$ (data not shown), a value well above the optimal soil temperature for root growth of European larch $\left(20{ }^{\circ} \mathrm{C}\right)$ (Kozlowski et al. 1991). Similarly, root growth of Japanese larch is known to decline at soil temperatures $>25^{\circ} \mathrm{C}(\mathrm{Qu}$ et al. 2009). Given the close phylogenetic relationship of hybrid larch to these species (Bergès and Chevalier 2001), we expected that for shallowplanted seedlings (especially in mounds), high soil temperatures would have impaired root functions, including water absorption (Boucher et al. 2001). However, we only detected this effect for deep-planted seedlings, which experienced lower maximum soil 
temperatures than shallow-planted trees $\left(22^{\circ} \mathrm{C}\right)$, and only via an indirect effect through nutrition. We thus hypothesize that this is indicative of a detrimental effect of high temperatures on the lower branch foliage of the seedlings, located near the heat emitted from the soil surface. This indirect impact was not apparent for shallow planted seedlings, whose foliage was located further from the soil. However we did not assess branch foliage damages or physiology near the soil. This assumption thus remains to be verified.

Unexpectedly, seedling foliar nutrition was positively related to vegetation cover, resulting in increased seedling height. We attribute this positive response to two possible factors. First, it is possible that seedlings with better foliar nutrition were planted in richer microsites, which also favoured the regrowth of more abundant non-crop vegetation, although we could not demonstrate this with the technique we used to estimate vegetation cover. Second, we suggest that there was a facilitation process (Callaway and Walker 1997), explaining the observed positive effect of the competing vegetation of foliar nutrition (Fig. 4; Table 4). At this early stage of growth, the input of non-recalcitrant litter from early successional non-crop species and fast mineralization processes could have enhanced soil nutrient availability to larch (MacLean and Wein 1978). Further measurements aiming at the effects of vegetation cover on growth and survival will help elucidate the role of the non-crop vegetation on seedling performance. This relationship between vegetation and seedling nutrition was not as strong for deeper-planted seedlings as it was for the shallow-planted ones, whereas a negative direct effect of the non-crop vegetation on growth was observed. This is difficult to explain, as one would have 
expected such an effect to be stronger on trees growing closer to competitors. We hypothesize that the potential facilitation effect was stronger overall (through surface litter fall), but only accessible to shallow-planted trees (thus explaining their very strong positive competition effect on nutrition), whereas deeper-planted seedlings were still effectively isolated, for the time being, from the positive influence of non-crop vegetation. These early observations will need to be confirmed over a longer period, as well as with a more comprehensive assessment of local environmental conditions at the scale of individual seedlings. This experiment was also designed for the longer-term assessment of competition intensity and the effect of different cleaning intensities (brush saw).

Many jurisdictions in the world are looking at the potential beneficial effects of more intensive forest management practices on small portions of the landscape as a way to increase conservation and more environmentally friendly practices elsewhere (Zhao et al. 2011; Paquette and Messier 2013). This is the case in Quebec, where areas of management intensification are being discussed for large-scale implementation (Barrette et al. 2014; Messier et al. 2009).The need to develop cost and environmentally efficient plantation techniques is thus important and urgent. We show that satisfactory early establishment of fast-growing hybrid larch is possible using only basic site preparation techniques such as single-pass disk trenching (low cost) or inversions using an excavator (low environmental impact). However our results need to be evaluated over both the midand long-term. This work also provides insight into the factors that drive the early performance of hybrid larch, sure to be helpful in the design of even more efficient 
plantation techniques for this species that was only recently made available to foresters in Quebec and elsewhere in operational quantities.

\section{Acknowledgements}

We thank P. Gaucher, C. Jenkins, M. Hänsel, É. Rousselle, T. André, Y. Gauthier, J. Carignan, S. Lemay, D. Létourneau and E. Gaillard for their technical support, D. Lesieur for his help in database management, I. Auger for her constructive advice regarding the statistical analyses, as well as M. Girard and many others at Resolute Forest Products (Mauricie, QC). Larch hybrids used in this study are the result of continuous selection efforts from the Québec provincial nurseries. We are indebted to D. Craven, D.

Kneeshaw, B. Harvey, two anonymous reviewers and the Associate Editor who provided helpful comments on an earlier version of the manuscript, as well as W.F.J. Parsons (CEF) for language revision. This study is part of the TRIAD initiative, with the collaboration of the Direction de la recherche forestière of the Ministère des Forêts, de la Faune et des Parcs du Québec (project 142332106), MITACS, and Resolute Forest Products. 


\section{References}

Balandier P, Collet C, Miller JH, Reynolds PE, Zedaker SM (2006) Designing forest vegetation management strategies based on the mechanisms and dynamics of crop tree competition by neighbouring vegetation. Forestry 79:3-27

Barrette M, Leblanc M, Thiffault N, Paquette A, Lavoie L, Bélanger L, Bujold F, Côté L, Lamoureux J, Schneider R, Tremblay J-P, Côté S, Boucher Y, Deshaies M-È (2014) Enjeux et solutions pour la sylviculture intensive de plantations dans un contexte d'aménagement écosystémique. For Chron (accepted)

Bergès L, Chevalier R (2001) Les exigences écologiques des mélèzes. In: Riou-Nivert P (ed) Le mélèze. Institut pour le développement forestier (IDF), Paris, pp 52-59

Bilodeau-Gauthier S, Paré D, Messier C, Bélanger N (2013) Root production of hybrid poplars and nitrogen mineralization improve following mounding of boreal Podzols. Can J For Res 43 (12):1092-1103. doi:10.1139/cjfr-2013-0338

Boateng JO, Heineman JL, McClarnon J, Bedford L (2006) Twenty year responses of white spruce to mechanical site preparation and early chemical release in the boreal region of northeastern British Columbia. Can J For Res 36 (10):2386-2399

Boucher J-F, Bernier P, Munson A (2001) Radiation and soil temperature interactions on the growth and physiology of eastern white pine (Pinus strobus L.) seedlings. Plant Soil 236 (2):165-174

Brooker RW, Maestre FT, Callaway RM, Lortie CL, Cavieres LA, Kunstler G, Liancourt P, Tielbörger K, Travis JMJ, Anthelme F, Armas C, Coll L, Corcket E, Delzon S, Forey E, Kikvidze Z, Olofsson J, Pugnaire F, Quiroz CL, Saccone P, Schiffers K, Seifan M, Touzard B, Michalet R (2008) Facilitation in plant communities: the past, the present and the future. J Ecol 96 (1):18-34

Bruno JF, Stachowicz JJ, Bertness MD (2003) Inclusion of facilitation into ecological theory. TREE 18:119-125

Bullock JM (2006) Chapter 4: Plants. In: Sutherland WJ (ed) Ecological Census Techniques. Second edition. Cambridge University Press, New York, pp 186-213

Callaway RM, Walker LR (1997) Competition and facilitation: A synthetic approach to interactions in plant communities. Ecol 78 (7):1958-1965

Carter KK, Selin LO (1987) Larch Plantation Management in the Northeast. North J Appl For 4 (1):18-20

de Chantal M, Rita H, Bergsten U, Löfvenius M, Grip H (2009) Frost heaving of Picea abies seedlings as influenced by soil preparation, planting technique, and location along gapshelterwood gradients. Silv Fenn 43 (1):39-50

Gagné P, Paquette A (2008) Revue de la littérature sur la préparation de terrain mécanique pour les mélèzes. Réseau Ligniculture Québec, Québec, CA

Gemmel P, Nilsson U, Welander T (1996) Development of oak and beech seedlings planted under varying shelterwood densities and with different site preparation methods in southern Sweden. New For 12:141-161

Grossnickle SC (2005) Importance of root growth in overcoming planting stress. New For 30:273-294

Grossnickle SC (2012) Why seedlings survive: influence of plant attributes. New For 43:711-738

Grossnickle SC, Heikurinen J (1989) Site preparation : Water relations and growth of newly planted jack pine and white spruce. New For 3:99-123

Hallsby G, Örlander G (2004) A comparison of mounding and inverting to establish Norway spruce on podzolic soils in Sweden. Forestry 77 (2):107-117

Holmgren M, Scheffer M, Huston MA (1997) The interplay of facilitation and competition in plant communities. Ecol 78 (7):1966-1975 
Hooper D, Coughlan J, Mullen M (2008) Structural equation modelling: guidelines for determining model fit. EJBRM 6:53-60

Kozlowski TT, Kramer PJ, Pallardy SG (1991) The physiological ecology of woody plants. Physiological ecology. Academic Press, San Diego

Kramer PJ, Boyer JS (1995) Roots and root systems. In: Water relations of plants and soils. Academic press, New York, pp 115-165

Lei P-W, Wu Q (2007) Introduction to Structural Equation Modeling: Issues and Practical Considerations. EM:IP 26 (3):33-43. doi:10.1111/j.1745-3992.2007.00099.x

Löf M, Dey DC, Navarro RM, Jacobs DF (2012) Mechanical site preparation for forest restoration. New For 43 (5-6):825-848

Longpré M-H, Bergeron Y, Paré D, Béland M (1994) Effect of companion species on the growth of jack pine (Pinus banksiana). Can J For Res 24:1846-1853

MacLean DA, Wein RW (1978) Weight loss and nutrient changes in decomposing litter and forest floor material in New Brunswick forest stands. Can J Bot 56 (21):2730-2749

Margolis HA, Brand DG (1990) An ecophysiological basis for understanding plantation establishment. Can J For Res 20:375-390

Messier C, Bigué B, Bernier L (2003) Using fast-growing plantations to promote forest ecosystem protection in Canada. Unasylv 54:59-63

Messier C, Tittler R, Kneeshaw DD, Gélinas N, Paquette A, Berninger K, Rheault H, Meek P, Beaulieu N (2009) TRIAD zoning in Quebec: experiences and results after five years. For Chron 85 (6):885-896

Miller H (1995) The influence of stand development on nutrient demand, growth and allocation. Plant Soil 168-169 (1):225-232. doi:10.1007/BF00029332

Munson AD, Margolis HA, Brand DG (1993) Intensive silvicultural treatment: impacts on soil fertility and planted conifer response. Soil Sci Soc Am J 57:246-255

Örlander G, Gemmel P, Hunt J (1990) Site preparation: A Swedish overview. Forestry Canada, British Columbia Ministry of Forests, Victoria, BC,

Örlander G, Hallsby G, Gemmel P, Wilhelmsson C (1998) Inverting improves establishment of Pinus contorta and Picea abies: 10-year results from a site preparation trial in northern Sweden. Scand J Forest Res 13 (2):160-168

Pallardy SG (2010) Transpiration, Plant Water Balance and Adaptation to Drought. In: Physiology of woody plants. Academic Press, San Diego, pp 325-366

Paquette A, Girard J-P, Walsh D (2011) Deep planting has no short or long-term effect on the survival and growth of white spruce, black spruce and jack pine. North J Appl For 28 (3):146-151

Paquette A, Messier C (2010) The role of plantations in managing the world's forests in the Anthropocene. Front Ecol Env 8 (1):27-34. doi:10.1890/080116

Paquette A, Messier C (2013) Chapter 13 - Managing Tree Plantations as Complex Adaptive Systems. In: Messier C, Puettmann K, J., Coates KD (eds) Managing forests as complex adaptive systems: Building Resilience to the Challenge of Global Change. EarthScan, New York, pp 299-326

Parkinson JA, Allen SE (1975) A wet oxidation procedure suitable for the determination of nitrogen and mineral nutrients in biological material. Commun Soil Sci Plan 6:1-11

Prévost M (1992) Effets du scarifiage sur les propriétés du sol, la croissance des semis et la compétition : revue des connaissances actuelles et perspectives de recherches au Québec. Ann For Sci 49 (3):277-296

Prévost M, Dumais D (2003) Croissance et statut nutritif de marcottes, de semis naturels et de plants d'épinette noire à la suite du scarifiage : résultats de 10 ans. Can J For Res 33 (11):2097-2107

Prévost M, Thiffault N (2013) La préparation de terrain (Chapitre 8). In: Larouche C, Guillemette F, Raymond P, Saucier J-P (eds) Le guide sylvicole du Québec, Tome 2 - Les concepts et 
l'application de la sylviculture. Ministère des ressources naturelles. Les publications du Québec, Québec, pp 134-157

Pugesek BH, Tomer A, von Eye A (eds) (2003) Structural Equation Modeling: Applications in Ecological and Evolutionary Biology. Cambridge University Press,

Qu L, Kitaoka S, Makoto K, Kuromaru M, Osaki M, Sasa K, Utsugi H, Koike T (2009) Rootshoot communication of the seedlings of Japanese larch and a hybrid species grown in different soil-temperature regimes. Landsc Ecol Eng 5 (2):115-123

R Development Core Team (2008) R: a language and environment for statistical computing. version 2.8.1 edn. R Foundation for Statistical Computing, Vienna, Austria

Robbins K (1985) Risks Associated with Growing Non-native Larches in Eastern North America. North J Appl For 2 (4):101-104

Rosseel Y (2012) lavaan: An R Package for Structural Equation Modeling. J Stat Softw 48 (2):136

Sahlén K, Goulet F (2002) Reduction of frost heaving of Norway spruce and Scots pine seedlings by planting in mounds or in humus. New For 24 (3):175-182. doi:10.1023/a:1021378228524

Saucier J-P, Robitaille A, Grondin P (2009) Cadre bioclimatique du Québec. Écologie forestière. In: Manuel de foresterie, 2nd ed. Ordre des ingénieurs forestiers du Québec. Éditions Multimondes, Québec, QC, pp 186-205

Schwan T (1994) Planting depth and its influence on survival and growth. A literature review with emphasis on jack pine, black spruce and white spruce. Northeast Science \& Technology, Timmins, Ontario

Shipley B (2000) Cause and Correlation in Biology: A User's Guide to Path Analysis, Structural Equations and Causal Inference. Cambridge University Press,

Sutherland BJ, Foreman FF (1995) Guide to the use of mechanical site preparation equipment in northwestern Ontario. Natural Resources Canada, Canadian Forest Service, Great Lakes Forestry Centre, Sault Ste. Marie, Ontario

Sutton RF (1993) Mounding site preparation: A review of European and North American experience. New For 7 (2):151-192

Sutton RF (1995) Advantages of deep planting black spruce. Canadian Forest Service, Sault Ste. Marie, Ontario

Tarroux E, DesRochers A, Girard J-P (2014) Growth and root development of black and white spruce planted after deep planting. For Ecol Manage 318:294-303. doi:10.1016/j.foreco.2014.01.032

Thiffault N, Cyr G, Prégent G, Jobidon R, Charette L (2004) Régénération artificielle des pessières noires à éricacées : effets du scarifiage,de la fertilisation et du type de plants après 10 ans. For Chron 80 (1):141-149

Thiffault N, Fenton NJ, Munson AD, Hébert F, Fournier RA, Valeria O, Bradley RL, Bergeron Y, Grondin P, Paré D (2013) Managing Understory Vegetation for Maintaining Productivity in Black Spruce Forests: A Synthesis within a Multi-Scale Research Model. Forests 4 (3):613-631

Thiffault N, Hébert F (2013) Le dégagement et le nettoiement. In: Larouche C, Guillemette F, Raymond P, Saucier J-P (eds) Le guide sylvicole du Québec - Tome 2. Ministère des Ressources naturelles, Les publications du Québec, Québec, QC, pp 244-271

Thiffault N, Jobidon R (2006) How to shift unproductive Kalmia angustifolia - Rhododendron groenlandicum heath to productive conifer plantation. Can J For Res 36 (10):2364-2376

Thiffault N, Roy V (2011) Living without herbicides in Québec (Canada): historical context, current strategy, research and challenges in forest vegetation management. Eur J Forest Res 130 (1):117-133. doi:10.1007/s10342-010-0373-4

Ung CH, Végiard S (1988) Problèmes d'inférence statistique reliés à la transformation logarithmique en régression. Can J For Res 18:733-738 
Végiard S, Ung CH (1993) Statistical inference problems related to the logarithmic transformation in regression: another method for interval estimation. Can J For Res 23:871-872

von der Gonna MA (1992) Fundamentals of mechanical site preparation. Forestry Canada, Pacific Forestry Centre, copublished by the BC Ministry of Forests, Victoria, BC

Walstad JD, Kuch PJ (1987) Forest vegetation management for conifer production. John Wiley \& Sons, New York, NY

Zhao F, Yang J, Liu Z, Dai L, He HS (2011) Balancing multiple objectives using a classificationbased forest management system in Changbai mountains, China. Env Man 48 (6):11361147 


\section{Tables}

Table 1. Description of the five site preparation treatments: Simple, Double adjacent,

Double intensive, Inversion and Mounds (see also Fig. 2), including disturbance rankings

from 1 (least disturbed) to 5 (most). Microsite level is related to the hypothesized effect on local growing conditions and therefore seedling performance. Stand level refers to the environmental effect of the different options (e.g. understory flora, soil erosion, among others).

\begin{tabular}{|c|c|c|c|}
\hline \multirow[t]{2}{*}{ Treatment } & \multirow[t]{2}{*}{ Description } & \multicolumn{2}{|c|}{$\begin{array}{l}\text { Disturbance } \\
\text { rankings at the level } \\
\text { of the }\end{array}$} \\
\hline & & Microsite & Stand \\
\hline Trenching & $\begin{array}{l}\text { T26 Bracke disk trencher mounted on a } \\
\text { skidder }-2 m \text { between trenches and } \\
\text { trees along a trench }(2500 / h a)\end{array}$ & & \\
\hline Simple $(\mathrm{T})$ & Conventional single pass & 1 & 3 \\
\hline $\begin{array}{l}\text { Double adjacent } \\
\text { (T-Da) }\end{array}$ & $\begin{array}{l}\text { Two passes over the same trench. } \\
\text { Furrows overlap each other by a few } \\
\mathrm{cm} \text {, thus producing a deeper }(3 \mathrm{~cm}) \text { and } \\
\text { wider }(4 \mathrm{~cm}) \text { treated area than the } \mathrm{T} \\
\text { treatment }\end{array}$ & 2 & 4 \\
\hline $\begin{array}{l}\text { Double intensive } \\
\text { (T-Di) }\end{array}$ & $\begin{array}{l}\text { Two passes over the same row, } \\
\text { amplifying disk angle (with respect to } \\
\text { the trencher) for the second pass, thus } \\
\text { producing deeper }(5 \text { and } 8 \mathrm{~cm}) \text { and } \\
\text { wider }(8 \text { and } 12 \mathrm{~cm}) \text { treated areas than } \\
\text { the T-Da and T treatments, respectively }\end{array}$ & 3 & 5 \\
\hline $\begin{array}{l}\text { Partial intensive } \\
(\mathrm{T}-\mathrm{Pi})\end{array}$ & $\begin{array}{l}\text { Same as T-Di, but applied every two } \\
\text { rows, thus leaving } 2-3 \text { m-wide } \\
\text { unprepared strips between the treated } \\
\text { areas. For the purpose of this study, } \\
\text { seedlings belonging to this treatment } \\
\text { were pooled with those of T-Di }\end{array}$ & 3 & $<3$ \\
\hline Mounding & $\begin{array}{l}220 \text { excavator equipped with a } 60 \mathrm{~cm} \text { - } \\
\text { wide bucket }-3 \mathrm{~m} \text { between mounds (and } \\
\text { planted trees }-1111 / \mathrm{ha} \text { ) }\end{array}$ & & \\
\hline $\begin{array}{l}\text { Inversions } \\
\text { (M-inv) }\end{array}$ & $\begin{array}{l}\text { Bucket excavates and upturns mineral } \\
\text { soil, creating an elevated mass }(20- \\
\left.30 \mathrm{~cm} \text { high and } 0.6-0.8 \mathrm{~m}^{2} \text { surface }\right)\end{array}$ & 4 & 1 \\
\hline
\end{tabular}


roughly conical in form, which is replaced in its original hole

Mounds (M) Same as M-inv, but the excavated, upturned material lies next to the hole created by the excavation 
Table 2. Repeated measures ANOVA results for hybrid larch growth as influenced by five site preparation methods, two planting depths, and time (initial dimensions plus two growing seasons). $\mathrm{n} \mathrm{df}=$ numerator degrees of freedom for height and ground-level diameter; $\mathrm{d} d f=$ denominator degrees of freedom. Please see text for sample size details.

\begin{tabular}{|c|c|c|c|c|c|c|c|}
\hline \multirow{2}{*}{$\begin{array}{l}\text { Source of variation } \\
\text { (fixed effects) }\end{array}$} & \multicolumn{4}{|c|}{ Height } & \multicolumn{3}{|c|}{ Diameter } \\
\hline & $\mathrm{n} \mathrm{df}$ & $\mathrm{d} d f$ & $F$-value & $P$-value & $\mathrm{d} d f$ & $F$-value & $P$-value \\
\hline Site Preparation (SP) & 4 & 8 & 4.78 & 0.029 & 8 & 0.89 & 0.511 \\
\hline Planting Depth (PD) & 1 & 10 & 2.25 & 0.165 & 10 & 9.70 & 0.011 \\
\hline $\mathrm{SP} \times \mathrm{PD}$ & 4 & 10 & 1.29 & 0.339 & 10 & 0.26 & 0.897 \\
\hline Time $(\mathrm{T})$ & 2 & 5734 & 9406 & $<0.001$ & 5729 & 15356 & $<0.001$ \\
\hline $\mathrm{SP} \times \mathrm{T}$ & 8 & 5734 & 13.67 & $<0.001$ & 5729 & 22.41 & $<0.001$ \\
\hline $\mathrm{PD} \times \mathrm{T}$ & 2 & 5734 & 3.02 & 0.049 & 5729 & 0.58 & 0.559 \\
\hline $\mathrm{SP} \times \mathrm{PD} \times \mathrm{T}$ & 8 & 5734 & 5.19 & $<0.001$ & 5729 & 5.12 & $<0.001$ \\
\hline
\end{tabular}


1 Table 3. Treatment effects on microsite variables measured in 2011 on sub-sampled trees. SP = Site Preparation; PD = Planting Depth;

2 PD was not included as a factor in the ANOVA (REML) for soil water and competing vegetation. Means followed by different letters

3 are significantly different (Tukey tests). We only compared site preparations for soil $\mathrm{T}^{\circ}$ since the interaction with depth was not

4 significant; least squares means (SE) for were $18.0(0.2){ }^{\circ} \mathrm{C}$ at $0-3 \mathrm{~cm}$, and $16.7(0.2){ }^{\circ} \mathrm{C}$ at $3-10 \mathrm{~cm}$. Maximum available sample size

5 (n) was 286 but varied between variables (see Methods).

\begin{tabular}{|c|c|c|c|c|c|c|c|c|c|c|}
\hline \multirow[t]{2}{*}{ Variables } & \multicolumn{5}{|c|}{ Site preparation treatment least squares means (SE) } & \multicolumn{5}{|c|}{$\mathrm{N}, P-$ values and $\mathrm{R}^{2}$} \\
\hline & $\mathrm{T}$ & T-Da & T-Di (T-Pi) & M-inv & $\mathrm{M}$ & $\mathrm{n}$ & SP & PD & $\mathrm{SP} \times \mathrm{PD}$ & $\mathrm{R}^{2}$ \\
\hline Foliar N (g/kg) & $18.2(1.2)$ & $17.5(1.2)$ & $16.5(1.1)$ & $16.6(1.2)$ & $18.1(1.2)$ & 283 & 0.81 & 0.84 & 0.21 & 0.14 \\
\hline Foliar P (g/kg) & $2.6(0.1)$ & $2.3(0.1)$ & $2.3(0.1)$ & $2.5(0.1)$ & $2.4(0.1)$ & 267 & 0.54 & 0.48 & 0.13 & 0.09 \\
\hline Foliar K (g/kg) & $7.9(0.4)$ & $8.2(0.4)$ & $7.7(0.3)$ & $7.9(0.4)$ & $8.0(0.4)$ & 267 & 0.76 & 1.0 & 0.25 & 0.07 \\
\hline Foliar $\mathrm{Ca}(\mathrm{g} / \mathrm{kg})$ & $1.8(0.2)$ & $1.9(0.2)$ & $1.7(0.1)$ & $1.8(0.2)$ & $1.7(0.2)$ & 267 & 0.98 & 0.89 & 0.52 & 0.09 \\
\hline Foliar Mg (g/kg) & $1.02(0.04)$ & $1.06(0.04)$ & $1.01(0.03)$ & $0.99(0.04)$ & $1.04(0.05)$ & 267 & 0.82 & 0.80 & 0.58 & 0.11 \\
\hline Soil water content $(\%)$ & $39.2(5.2) \mathrm{a}$ & $44.1(5.2) \mathrm{a}$ & $43.5(5.1) \mathrm{a}$ & $38.0(5.2) \mathrm{a}$ & $28.5(5.2) \mathrm{b}$ & 286 & $<0.001$ & NA & NA & 0.44 \\
\hline Soil temperature $\left({ }^{\circ} \mathrm{C}\right)$ & $16.6(0.3) \mathrm{a}$ & $16.8(0.3) \mathrm{a}$ & $17.2(0.2) \mathrm{a}$ & $17.2(0.3) \mathrm{a}$ & $19.1(0.3) b$ & 286 & $<0.001$ & 0.01 & 0.49 & 0.45 \\
\hline Competing veg. (\%) & $53(0.9)$ & $49(0.9)$ & $39(0.9)$ & $46(0.9)$ & $55(0.9)$ & 152 & 0.53 & NA & NA & 0.46 \\
\hline
\end{tabular}


7 Table 4. Test values and explained variance $\left(\mathrm{R}^{2}\right)$ of the SEM model factors (see Fig. 4), and their 8 effects on height growth of hybrid larch seedlings.

\begin{tabular}{|c|c|c|c|c|c|}
\hline \multirow{2}{*}{$\begin{array}{l}\text { Arrows } \\
\text { From }\end{array}$} & \multirow[b]{2}{*}{ To } & \multicolumn{2}{|c|}{$0-3 \mathrm{~cm}$} & \multicolumn{2}{|c|}{$3-10 \mathrm{~cm}$} \\
\hline & & $\mathrm{R}^{2}$ & $P$-value & $\mathrm{R}^{2}$ & $P$-value \\
\hline Soil water content & \multirow{4}{*}{ Height } & \multirow{3}{*}{0.25} & 0.056 & \multirow{3}{*}{0.33} & 0.002 \\
\hline Soil temperature & & & 0.113 & & 0.877 \\
\hline Nutrient latent variable & & & 0.002 & & 0.002 \\
\hline Competing vegetation & & & 0.690 & & 0.058 \\
\hline Soil water content & & & 0.602 & & 0.035 \\
\hline Soil temperature & Nutrient (latent) & 0.32 & 0.305 & 0.17 & 0.019 \\
\hline \multirow[t]{2}{*}{ Competing vegetation } & & & $<0.001$ & & 0.067 \\
\hline & $\mathrm{N}$ & 0.75 & $<0.001$ & 0.69 & $<0.001$ \\
\hline \multirow[t]{2}{*}{ Nutrient (latent) } & $\mathrm{P}$ & 0.39 & $<0.001$ & 0.60 & $<0.001$ \\
\hline & $\mathrm{Ca}$ & 0.48 & $<0.001$ & 0.41 & $<0.001$ \\
\hline \multicolumn{3}{|l|}{ Fit indices } & $\mathrm{n}=70$ & \multicolumn{2}{|c|}{$\mathrm{n}=72$} \\
\hline \multicolumn{3}{|l|}{ Chi-square $(P$-value $)$} & 0.301 & \multicolumn{2}{|c|}{0.647} \\
\hline \multicolumn{3}{|c|}{ Comparative fit index (CFI) } & 0.982 & \multicolumn{2}{|c|}{1.000} \\
\hline \multicolumn{3}{|c|}{ Root mean square error of approximation ( $P$-value $)$} & 0.426 & \multicolumn{2}{|c|}{0.752} \\
\hline
\end{tabular}




\section{Figure captions}

12 Fig. 1. Layout of the split-plot experimental design covering $\sim 27$ ha with details of one

13 experimental unit. Each block (a) was divided into six main plots (b), each around one hectare,

14 that were treated with six mechanical site preparation methods (Simple (T), Double adjacent (T-

15 Da), Double intensive (T-Di), Inversions (M-inv), Mounds (M), and Partial intensive (T-Pi) (see

16 Table 1); the latter is pooled with Double intensive for this study). These main plots were further

17 divided into two subplots (c), which were planted with hybrid larch seedlings at one of two

18 planting depths $(0-3 \mathrm{~cm} ; 3-10 \mathrm{~cm})$. Finally, two circular sampling plots (d) were established

19 inside each subplot as sampling units. All treatments within plots and subplots were assigned

20 randomly.

22 Fig. 2. Schematic representation of the site preparation treatments. Top row (trenching): Simple,

23 Double adjacent, and Double intensive. Bottom row (mounding): Inversion and Mounds.

25 Fig. 3. Mean height and ground-level diameter of hybrid larch seedlings at the time of planting

26 and after the first two growing seasons, as influenced by site preparation and planting depth.

27 Results are presented as mean \pm SD; total sample sizes range between 2021 and 1776, depending

28 upon year and response (see text for details). See Table 1 for treatment descriptions, as well as

29 the Results section for the statistical significance of a priori contrasts comparing slopes for height 30 and diameter increments. 
32 Fig. 4. Results of structural equation modelling (SEM) analyses applied to a subsample of hybrid

33 larch seedlings that were planted at two depths, a) $0-3 \mathrm{~cm}$ and b) $3-10 \mathrm{~cm}$. White squares and

34 circles are factors affecting the response variable (grey squares). Circles represent a foliar

35 nutrient-based latent variable (foliar N, P and Ca levels). Arrows are causal paths and their

36 thickness reflects the importance of the coefficients ( 0 to 1 ), with 1 being the strongest value

37 (solid lines, positive; dashed lines, negative). All possible links were tested, but only significant

$38(P<0.05)$ links and their completely standardized values are presented (near significance $(P<$

390.1 ) is indicated with an *) (see Tab. 4). For the sake of clarity, error paths are omitted. 
Blocks

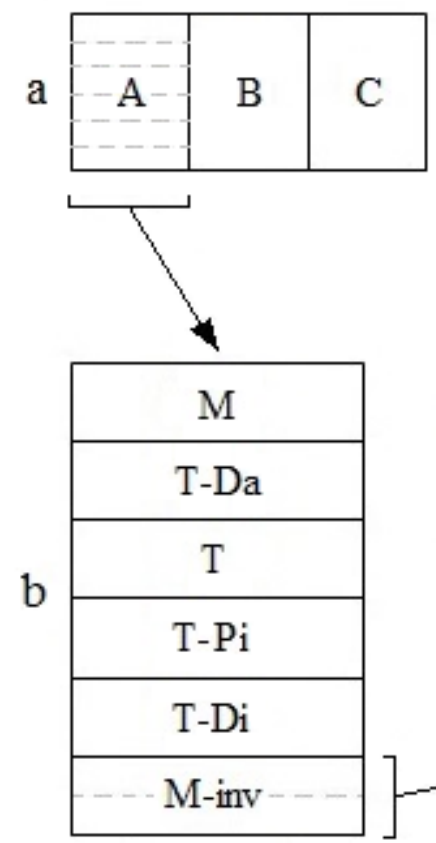

Site preparation treatments
Circular plots

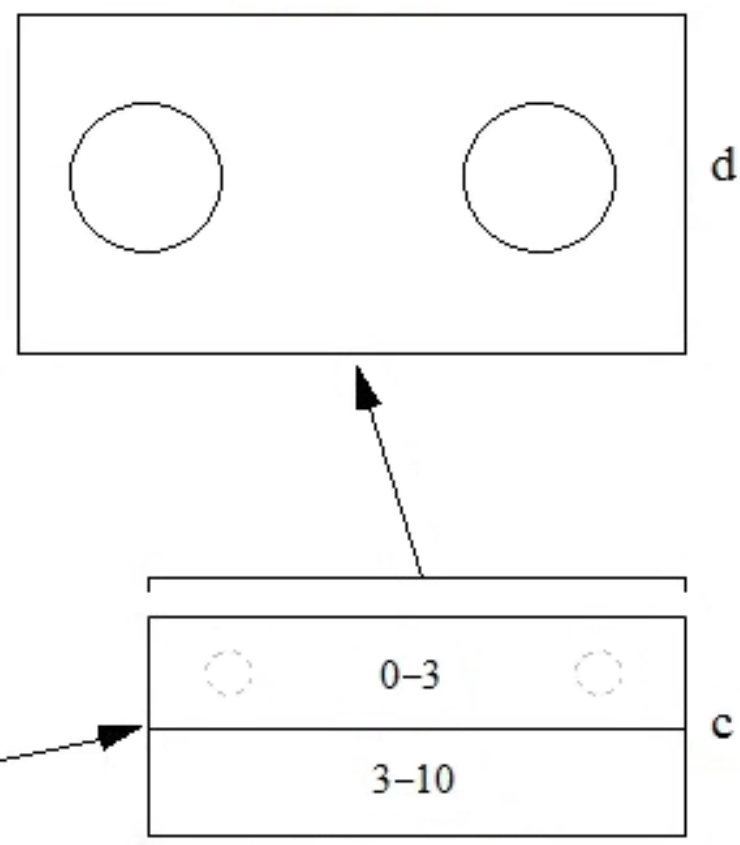

Plantation depth

treatments 


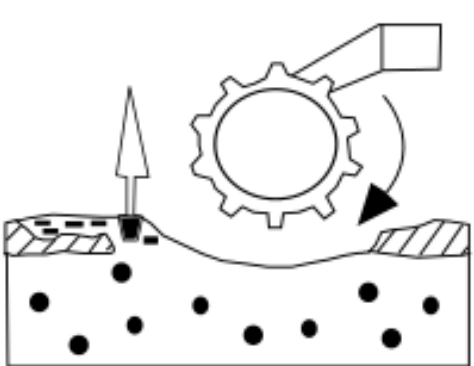

Simple

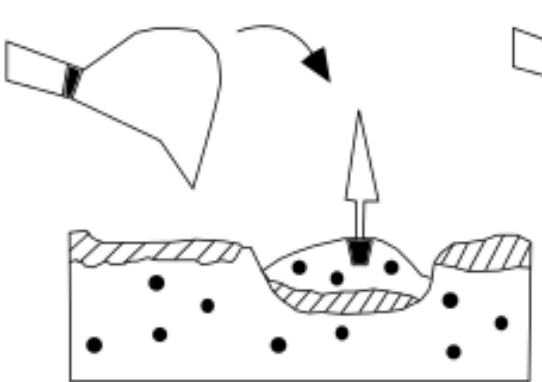

Inversions

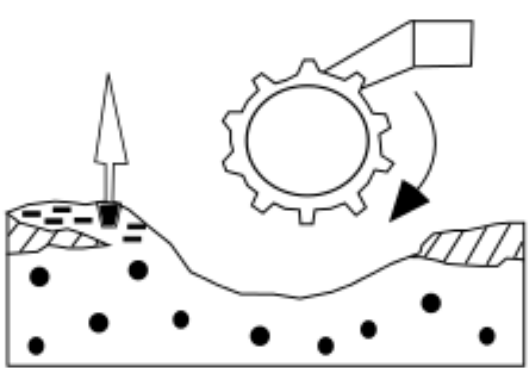

Double adjacent

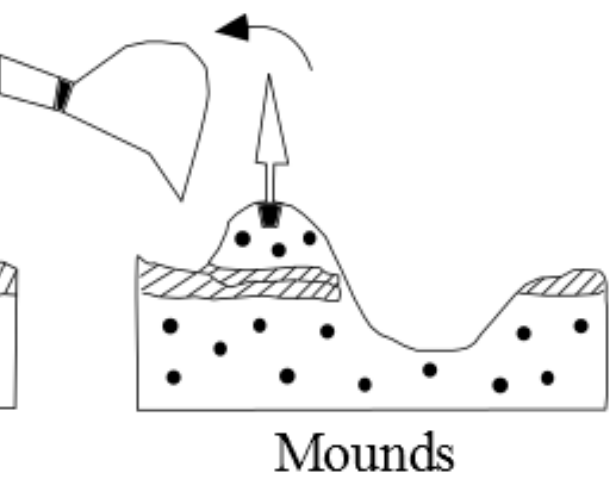

$\square /$ Organic layer

$\because$ Mineral soil

- Mixed mineral soil and organic layer

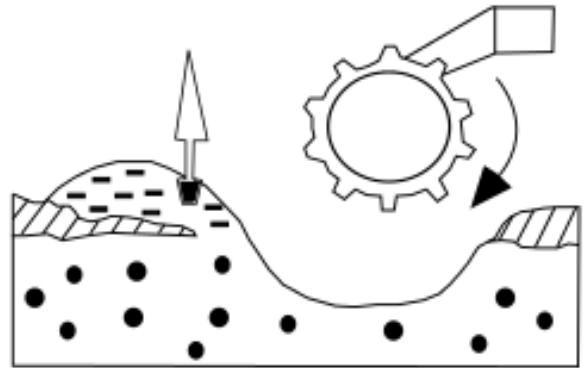

Double intensive 
Plantation depth $(\mathrm{cm})$

$0-3$
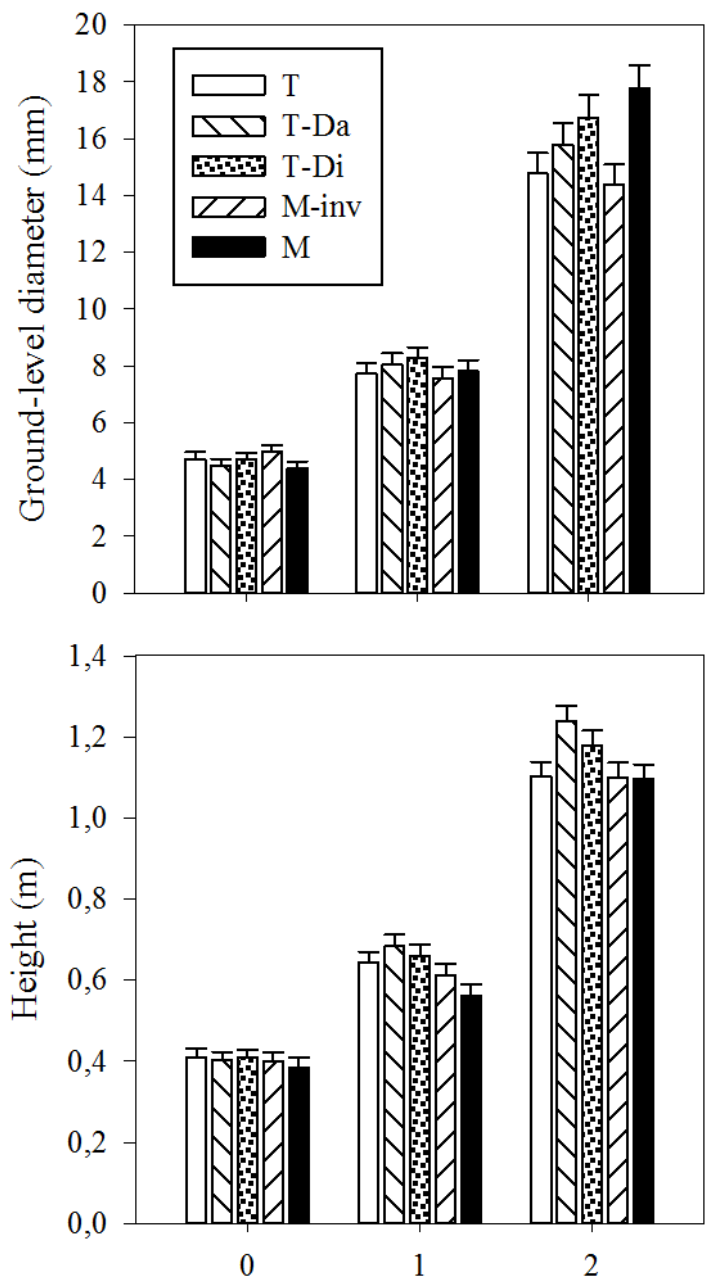

3-10
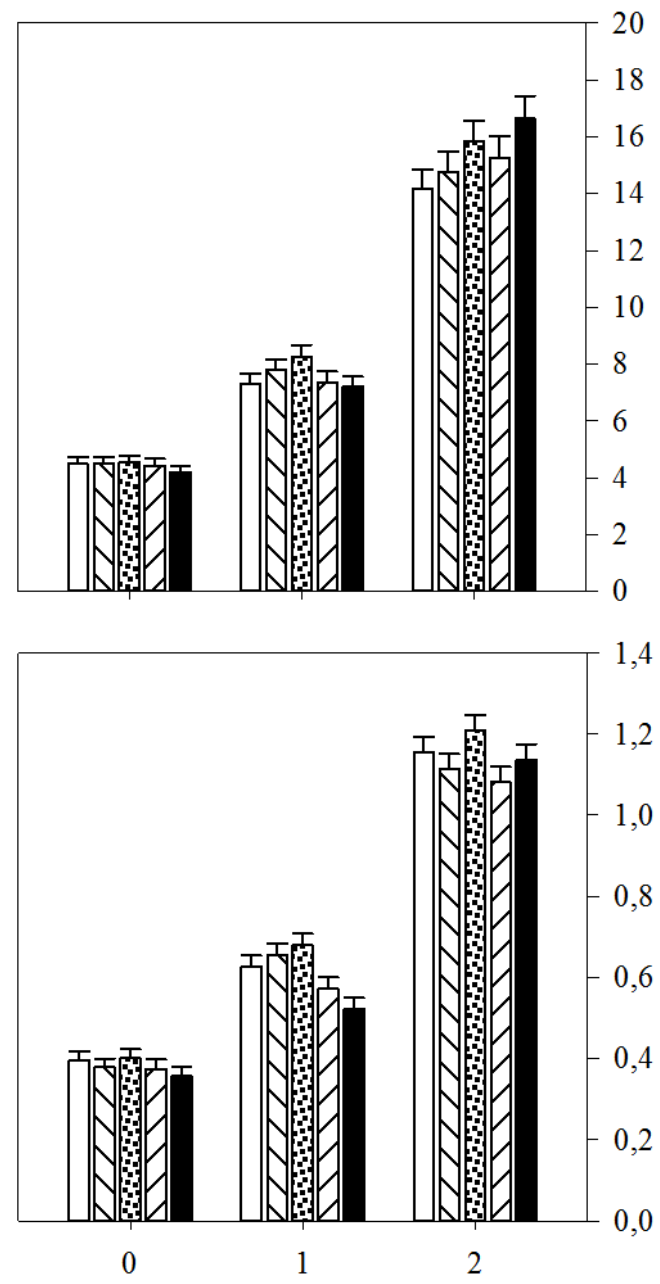

Growing seasons after planting 

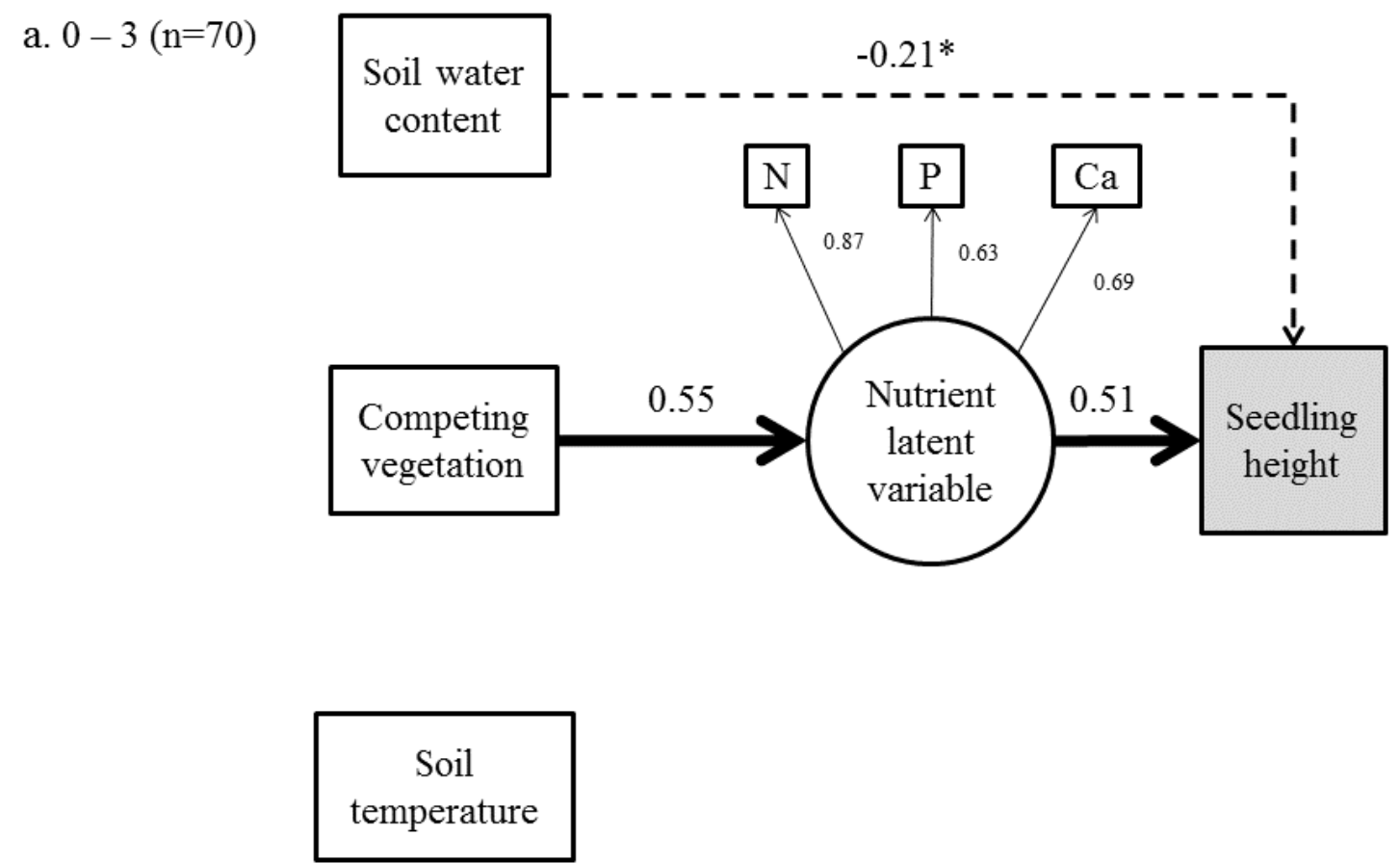


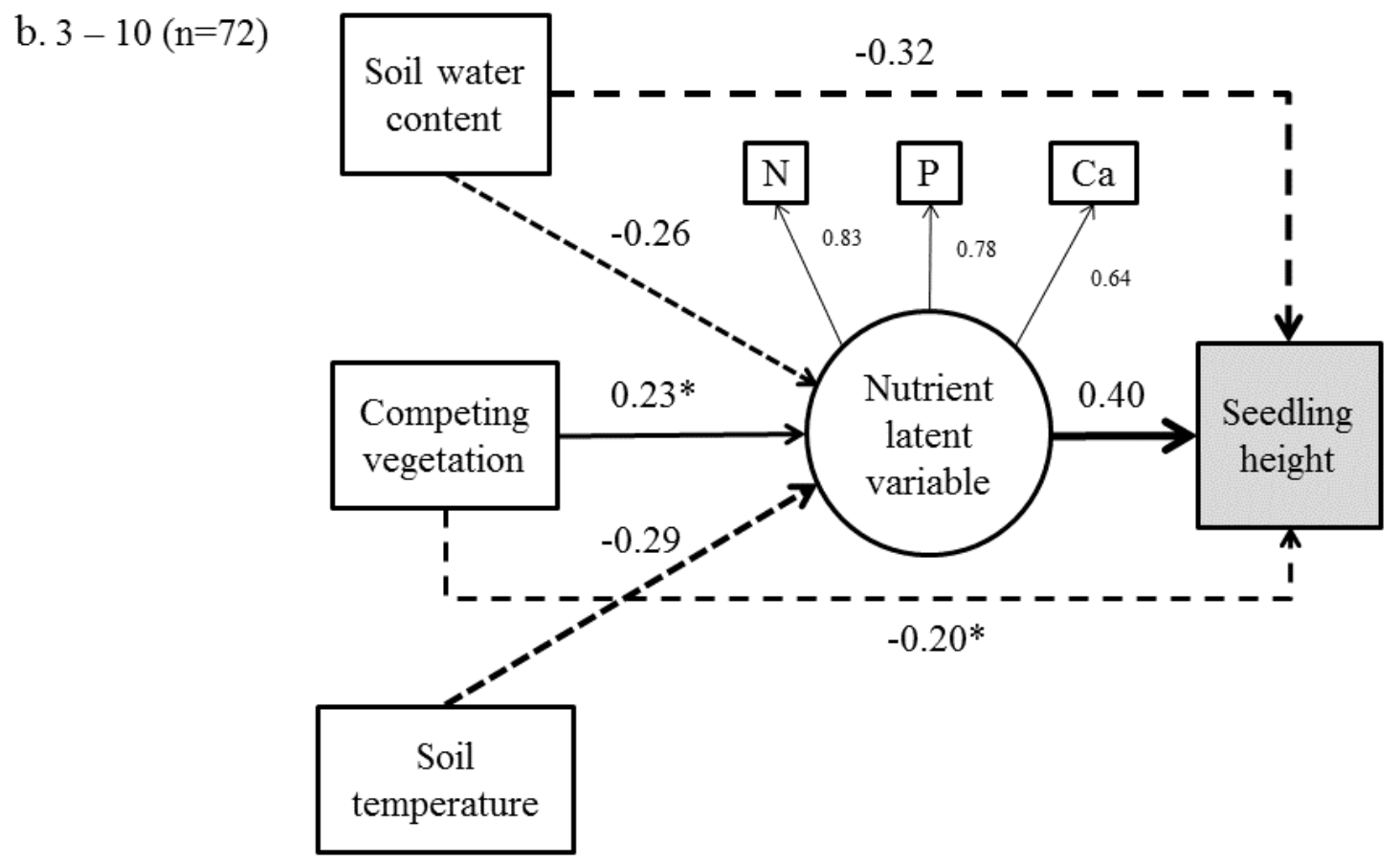

